る(図 $2 \mathrm{c})$.

\section{9 おわりに}

こうして見てゆくと，軟体動物での先発の解析の結果 は, 脊椎動物の系で追認され,「アメフラシと人間は違 うよ」という当初の愤疑論（ないし人間別格主義）を吹 き飛ばしてきた．ある系で A キナーゼが働き, 別の系 で C キナーゼが㗢いているといった違いはあるだろ う.ある系で燐酸化される基質は $\mathrm{K}$ チャンネルだが， 別の系では $\mathrm{Ca}^{2+}$ 排出装㯰かもしれない. しかし, 筆者 の感覚ではそれらは本質的な差とは思われない，記憶の 短期相に比定される既存シナプスの伝達効率調節現象に 関しての软体動物モデルの有効性は疑いない，

しかし, 第 2 節の問題に戻って, 記憶の長期相の解 析にもその有効性が保証されるだろうか．筆者は人間別 格主義者ではないが，この点については疑問をもつ。

アメフラシにも長期記譩と呼ばれる現象はある。しか し, 現在までにえられた結果から判断する限り，短期記 憶（既存シナプスの伝達効率变化）と同じ装置が働いて いるようである，伝達効率の急性的变化をもたらした蛋 白質の橉酸化・脱燐酸化機構が, DNA の転写・蛋白質 の新合成を伴うなんらかの機構を通じて長期的に維持さ
れる形式のように思われ ${ }^{3-13)}$ ，春椎動物で想定されて いるような，新しいシナプスの形成を含む新回路の成立 による機構は考えられていないようだ.

人間ないし哺乳類別格主義に立つ人は，今度こそ本領 を発揮すべき部分と信じて努力を傾注しているし，そう した主義にくみしない人も，末知の鉣脈が隠されている 金山として, 記憶の長期化（固定化）機構の研究に参入 しつつある. 数年後、こうした成果をまとめて本誌に報 告できるようになることを期待しつつペンを置く.

\section{文献}

1) 塚原什晃，科学，55, 404 (1985).

2) 黑田洋一郎, Dementia, 2, 179 (1988).

3) J. Goclet ct al, Nature, 322, 419 (1986).

4) D. Alkon, Science, 226, 1037 (1984).

5) D. Piomelli et al, Nclure, 328, 38 (1987).

6) S. Rayport et al, J. Neurosci., 6, 759 (1986).

7) 久埸健司，生体の科学，38，305（1987).

8）小沢激司，生体の科学，38, 589 (1987).

9) M. Sakurai, J. Physiol., 394, 463 (1987).

10）小良明彦，工藤佳久，生体の科学，38，597(1987).

11) J. Connor et al, Science, 240,649 (1988).

12) P. Montalolo et al, Nature, 333, 171 (1988).

13) S. Schacher et al, Science, 240, 239 (1986).

14）川人茂男, 生体の科学，37，239（1986）。

\title{
3ママメ科植物幼根の平衡細胞 における重力応答機構
}

\section{石川秀夫}

\section{1 序 論}

高等植物の重力に対する応答は古くて新しい研究課題 である．研究の源は約二百年以上前に遡ることができ， 進化論で有名な C. Darwin 博士は既に 1880 年. その 著書 "The Power of Movement in Plants" $"$ の中 で，幼根の先端が重力刺激に敏感であり，なんらかの形 で重力情報が伸長域（図1）に伝達されていると予見し ている，重力情報伝達物質探しを通して，植物ホルモン 研究がその後進んだことは有名である.また 1960 年代 以降の人工衛星, さらに 1981 年のスペースシャトル打 ち上げに伴い，微小重力環境が身近かな存在よなってき て, この分野の研究が急速に進展し始めている. 一方最

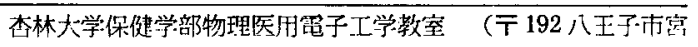
下町 476 )
近約 20 年間に, トランジスタや IC が発達したことも 見逃せない，その結果, 精度良く植物組織の表面電位, 膜電位や組織周辺の局所電流が観測され, 重力と電気現 象との関係が明らかになってきている、ただ植物の電気 現象は, まだ動物の神経細胞における情報伝達の様には その役割が明確になっていない，現在までのところ，植 物ホルモンの組織内不均等分布が, 一方では不均等成長 をおこし屈曲を生じさせ, 他方では種々の電気現象を引 き起こすと考元るのが一般的となっているが確証はな い. 今後, 全体を見渡す研究を遂行する上で, 電気化学 を専門とする研究者のこの分野への参加が求められてい る所以である。本稿では，いままでに得られている重力 と電気現象との関係について概観する。 


\section{1 膜電位}

\section{2 膜電笑之組䅧内電位分布}

一般に植物細胞の表面は細胞膜で覆われており, 外溶 液との間の界面を形成している。この細胞膜に起電性イ オンポンプといわれる一種の蛋白質 (ATPase) があ る. 起電性イオンポンプは動植物を問わずあら沙る生物 に存在し，その機能が細胞の性質を決定しているといつ てもよい，このポンプの活性は，膜電位（細胞外溶液を 基準としたときの細胞内の電位）上強い相互関係を有し ていることが知られている。

細胞膜は半透膜として性質を有することが知られてお り，そのため細胞内外のイオン濃度差により拡散電位が 発生する. 高等植物の場合, カリウムイオンが細胞中に 高濃度で蓄積されているので，拡散電位に相当する膜電 位は普通マイナスであり，この電位を膜電位の受動成分 という。ところが実際に測定される膜電位はこの膜電位 の受動成分よりもっとマイナスになる．このような現象 が起こるのは，活性化している起電性イオンポンプの寄 与(例えばプロトンが細胞内から細胞外に積極的に放出 さ机ること）により，膜電位が受動成分よりさらにマイ ナス側に変化して，膜を介したイオンの輸送がバランス することを示している．この2つの成分（膜電位の受動 成分よポンプ活性化による成分）をおおまかに分離する には。ポンプ活性の阻害郕なぼを使うのが簡便である． ポンプの活動が止まれば，ポンプ活性化による成分は失 われて，膜電位は受動成分だけになるとみなして良い， したがって膜電位の受動成分の大きさをあらかじめ知っ てい机ば．膜電位のダイナミックな変化からか゚ンプ活性 の経時変化を予想できる2゙.

\section{2 根の成長亡重力屈性}

根は図 1 に示すように多くの細胞が規則的に配列し ている．根の先端には成長点があり，ここで細胞分裂が 集中的に行なわれる，個々の細胞は分裂域で分裂して数 が增えた後，分裂を止めて伸長肥大するようになる。 そ の結果分裂域は伸長肥大するようになった細胞群（伸長 域）によってたえず先に押しやられ，根はその長さが伸 び続けることになる。したがって，細胞は分裂域，伸長 域。成熟域の順に新しい順に並んでいる。

根冠細胞はこれら伸長現象を起こす一群の細胞とは別 個に成長点で分裂し，最終的には死細胞となって脱落し ていく，根冠の中央部に細胞内にデンプン粒を含んだ平 衡細胞 (statocytes) と呼ばれる特殊な細胞群がある. デンプン粒が耳石と同じ役割を持つと考え，重力感受は この平衡細胞で行なわ机ていると考元られている.

鉛直に伸びる根は根軸の周りに同心状に組織が形成さ れている，根を傾けることで，根軸と重力の方向之の間 に差ができる之，根は伸長域で不均等に伸長し(図 2), 結果的に根端（分裂域と根冠）の根軸が重力方向上一致

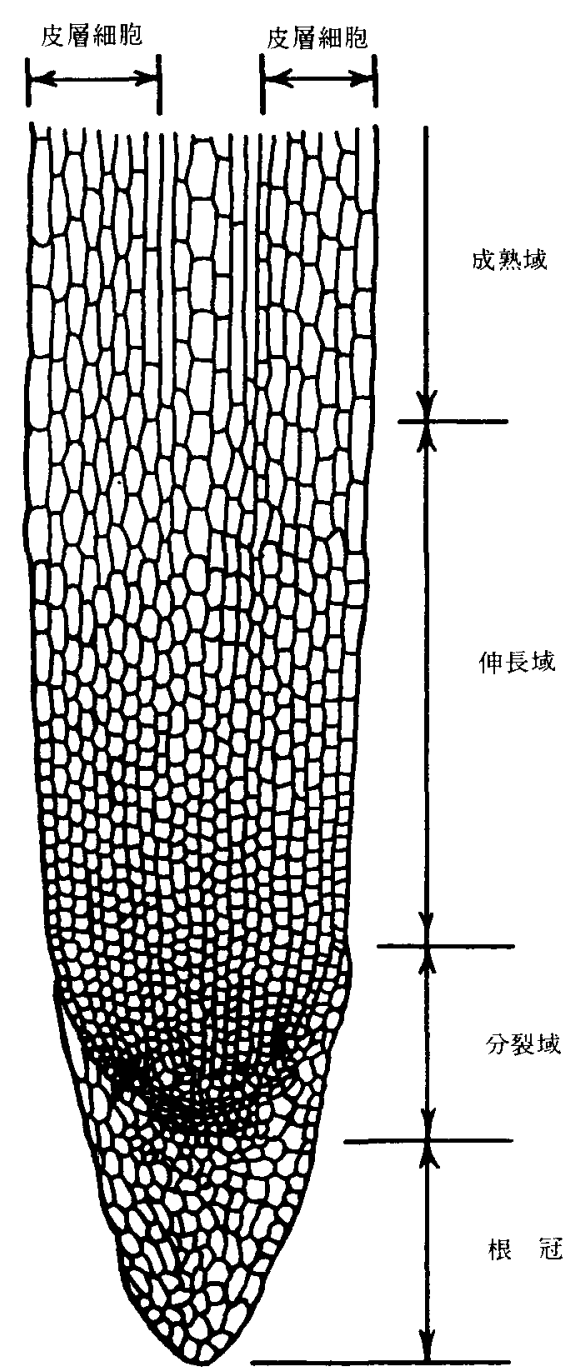

図 1 根の断面図

するようになる。根を傾けた際に重要なのは根全体とし てみる上，伸長速度は鉛直なままの根より抑制される点 である（図2の（垂直根の両側）に対する（水平根の上 側）上(水平根の下側））。細胞レベルでこの現象を説 明すれば，水平に傾けられてた根の下側伸長細胞は上側伸 長細胞に較べてより強く伸長が阻害されるが、上側伸長 細胞も鉛直なままであった時よりは伸長阻害されてい る。

各細胞は細胞膜で外溶液を介して間接的に紫がってい るだけでなく、細胞間連棓と呼ば㧈るパイプで直接結ば れている，細胞群は，互いに連合して，ひとつの組織と して機能している，そこで重力の影響を知るために，組 織内外の何筒所かでの電気現象（例えば上側亡下側伸長 細胞の膜電位）を湘定すれば，個々の細胞機能が明らか 


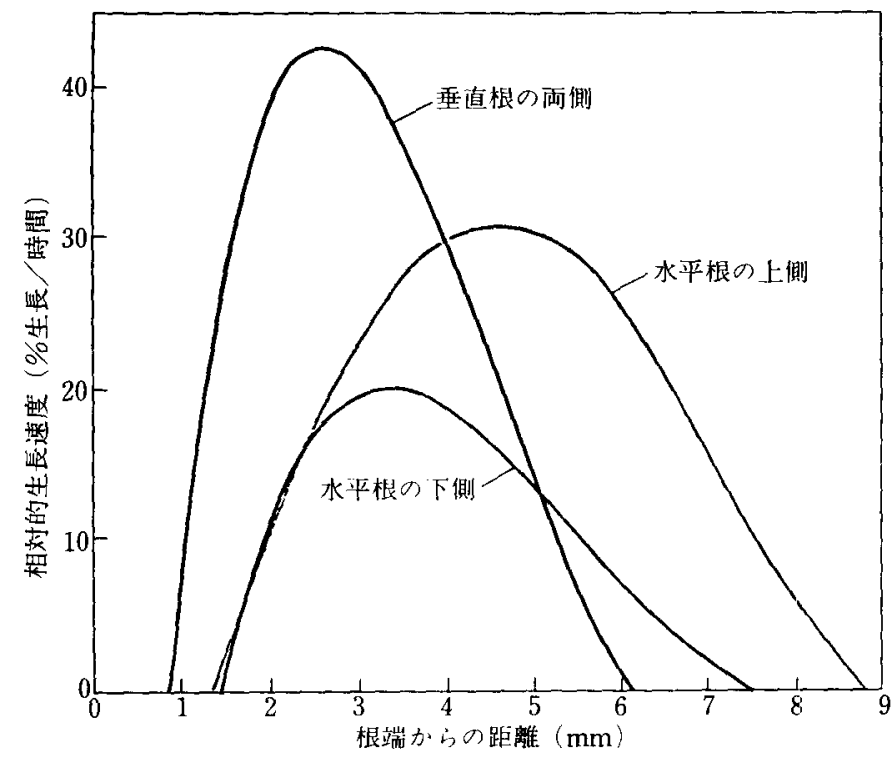

図 2 伸長域の伸長速度（提供: オ八イオ州立大学工 バンス教授)

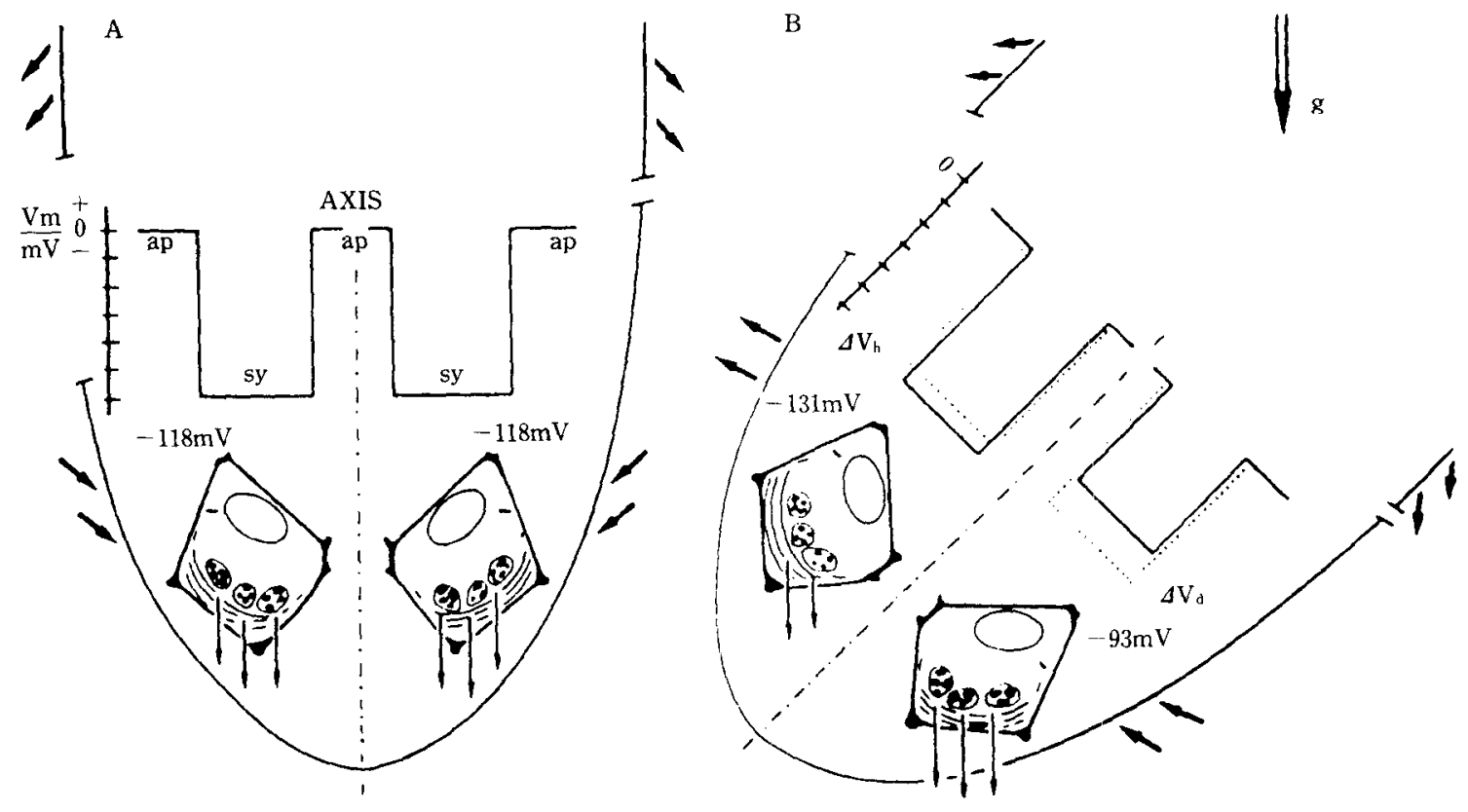

図 3 根冠の平衡細胞の配置の模式図の重力刺激に伴う膜電位分布 ${ }^{3)}$

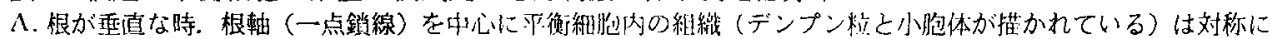

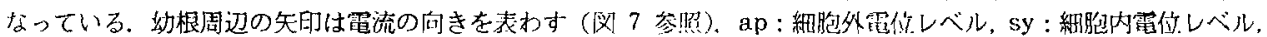

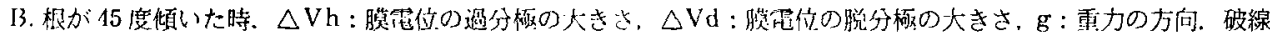

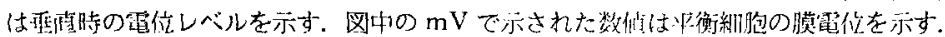


になるだけでなく，各細胞間の相互関係すなわち組織機 能を明らかにできる可能性がおる。

\section{3 根内の電位分布}

鉛直に伸びる根では，皮層細胞（伸長域と成熟域で根 軸上にある蜝管を同心円状に取り囲む 6 層ないし 7 層 の細胞，図 1）も根冠細胞も共に根先端からの距離が同 じ細胞同士は全て同一の膜電位である，ところが根を順 けると，下部になった細胞程浅い膜電位（小さい電位 差）となり，角度が大きい程電位は浅くなることがわ かった．上部は逆に根を傾けると鉛直な場合より膜電位 が深くなるが，その変化は下部に較べると小さいことが わかった（図 3”）が根冠平衡細胞，図 41) が伸長皮層 細胞).

さらに上部上下部の違いによる電位差が呼吸依存的な イオン輸送に因るのか，それ亡も単に伸長皮層細胞内の イオン浱度の差に因るのかを判別するために呼吸阻害剤 である DCCD を外溶液中に投与した（図 4の+DCC D). DCCD の添加に上り全て膜電位が脱分極した（浅 くなった). 脱分極の大きさ(变化した電位の絶対値) は，常に上部（伸長の活発な部位）ほど大きい，しかも
DCCD を加えたことで脱分極した後の膜電位（受動的 な電位成分）の大きさも上部の方が大きい。これは根上 部の細胞内イオン（とりわけカリウムイオン）濃度が根 下部の細胞内イオン濃度より高いことを示している。す なわち，根上部で呼吸依存的にカリウムイオンを皮層練 胞内に吸収し，蓄皘した結果之考えられる。なぜなら， 幼根を水平に置いてからの経過時間が長いほど, 幼根上 部の受動的電位成分は堌大する. 本実験の結果によれ ば，水平に監いたマメ科植物の幼根が屈曲するのは，伸 長域下部の起電性イオンポンナ゙が伸長域上部の起電性イ オンポンブに較べて抑制されたため，細胞内の $\mathrm{K}^{+}$濃度 の相違を通して根内部に浸透压分布を生じ，その結果水 の流入と細胞伸長の不均一が起きたと考元られる.

\section{4 膜雷位の経時変化}

先に示した C. Darwin の予見以来，根の重力に対す る応答は，まず根冠にあるデンプン粒を含んだ平衡細胞 の重力感受に始まり，次にその刺激が植物の成長を調整 するなんらかの因子（成長調整因子）に变換され，この 因子は伝達物質としての機能も合わせ持って重力情報を 伸長域に伝え, そして 10 分から 30 分後に, 最終的に伸
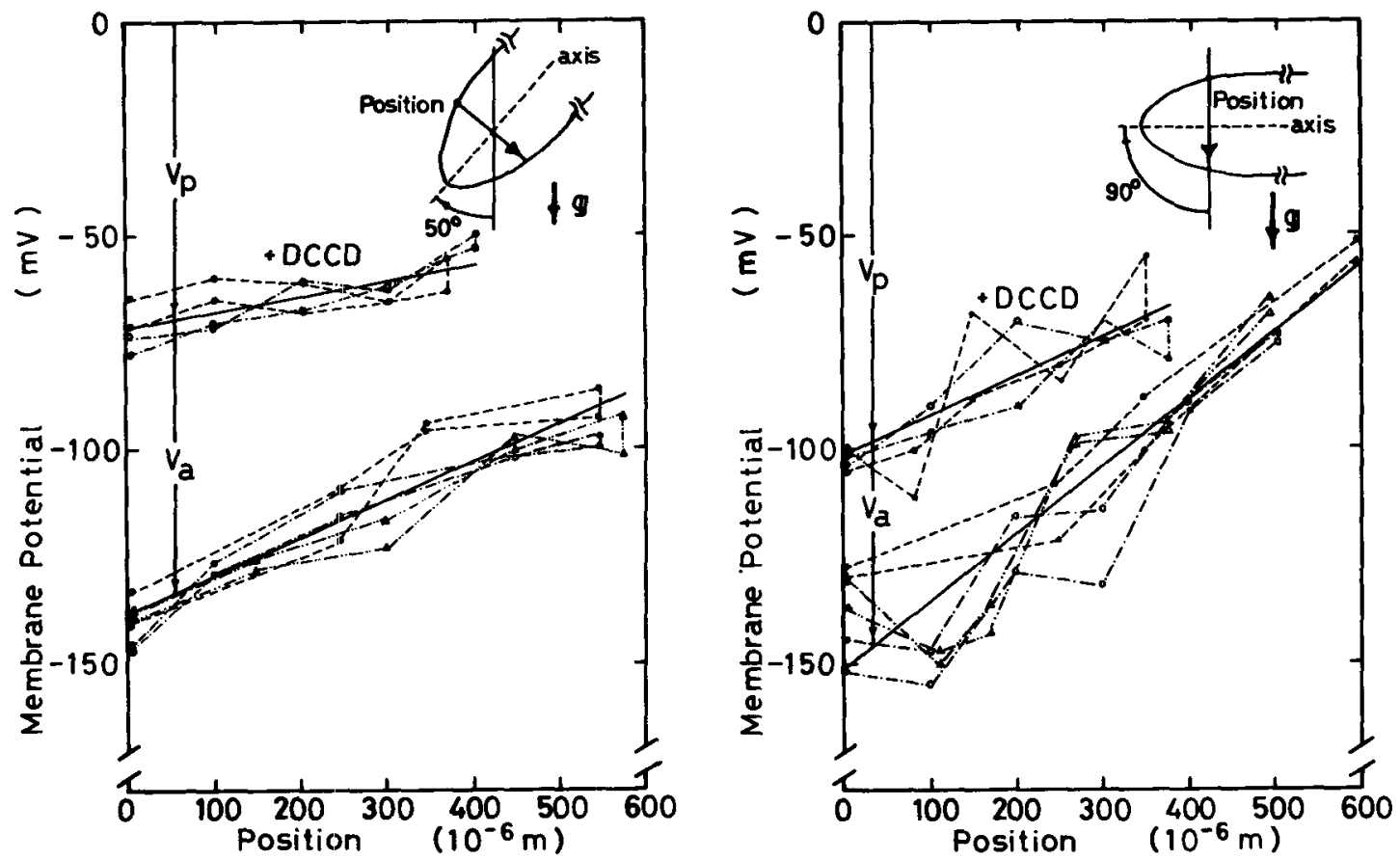

図 4 伸長域の皮層細胞電位分布

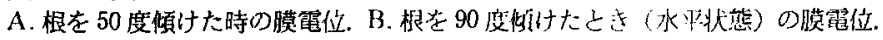

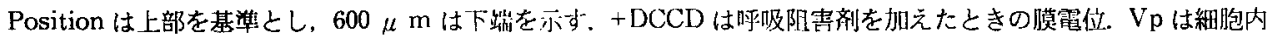
のイオン濃度（特にカリウムイオン）に依存し，Vaは起雷性イオンポンプの活性に依存している.

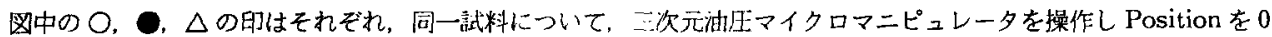
からだんだん増加させ，その後城少させ，また０に应す過程（盺間を結ぶ破線で示してある）で得られた膜電位を 表わす. 


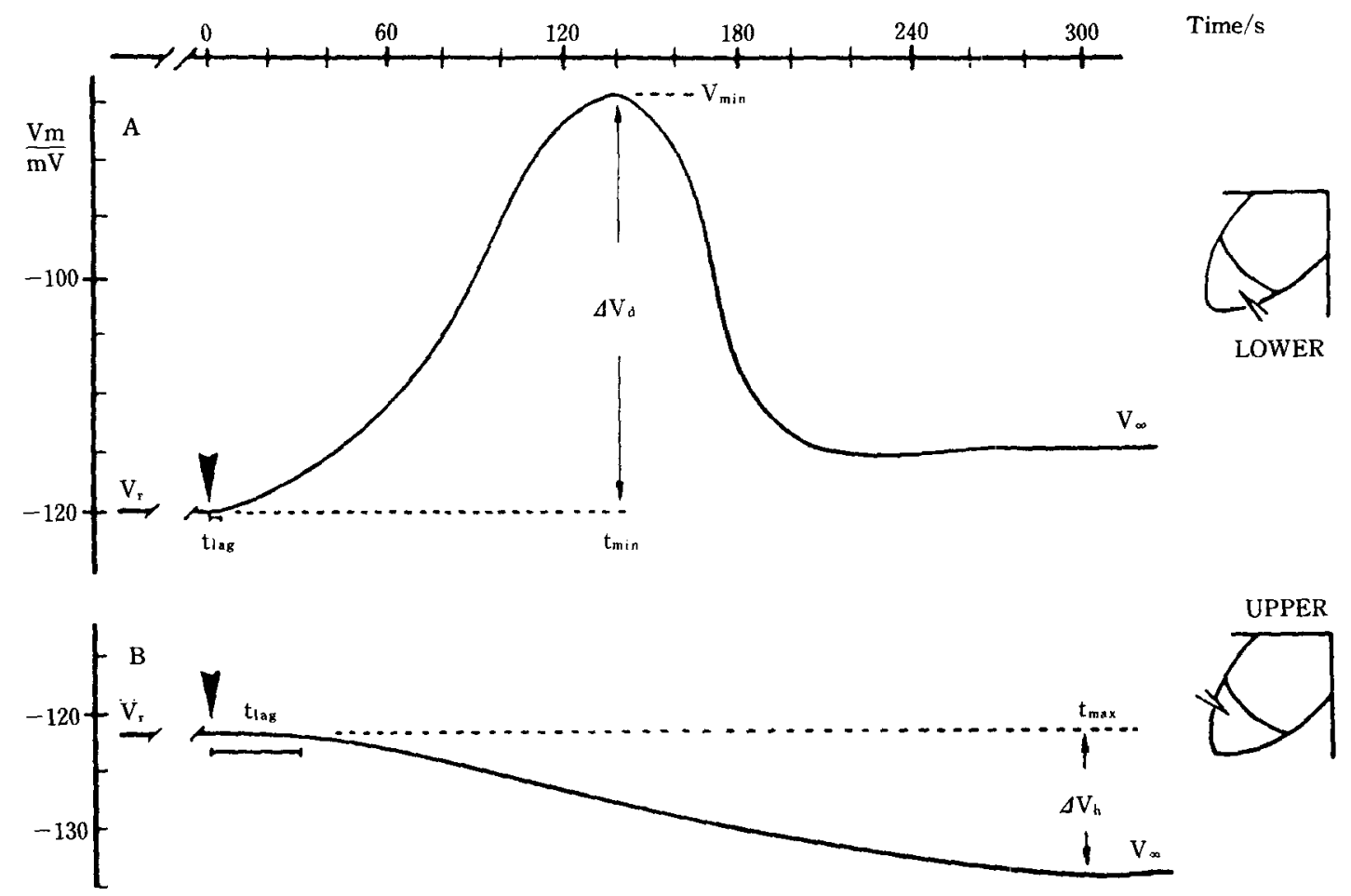

図 5 平衡細胞におりる膜電位の経時変化

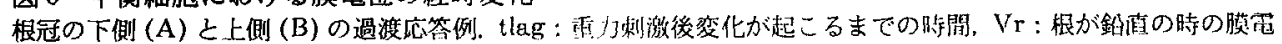
位, $\triangle \mathrm{Vh}$ と $\triangle \mathrm{Vd}$ は圈 3 の説朋と同じ.

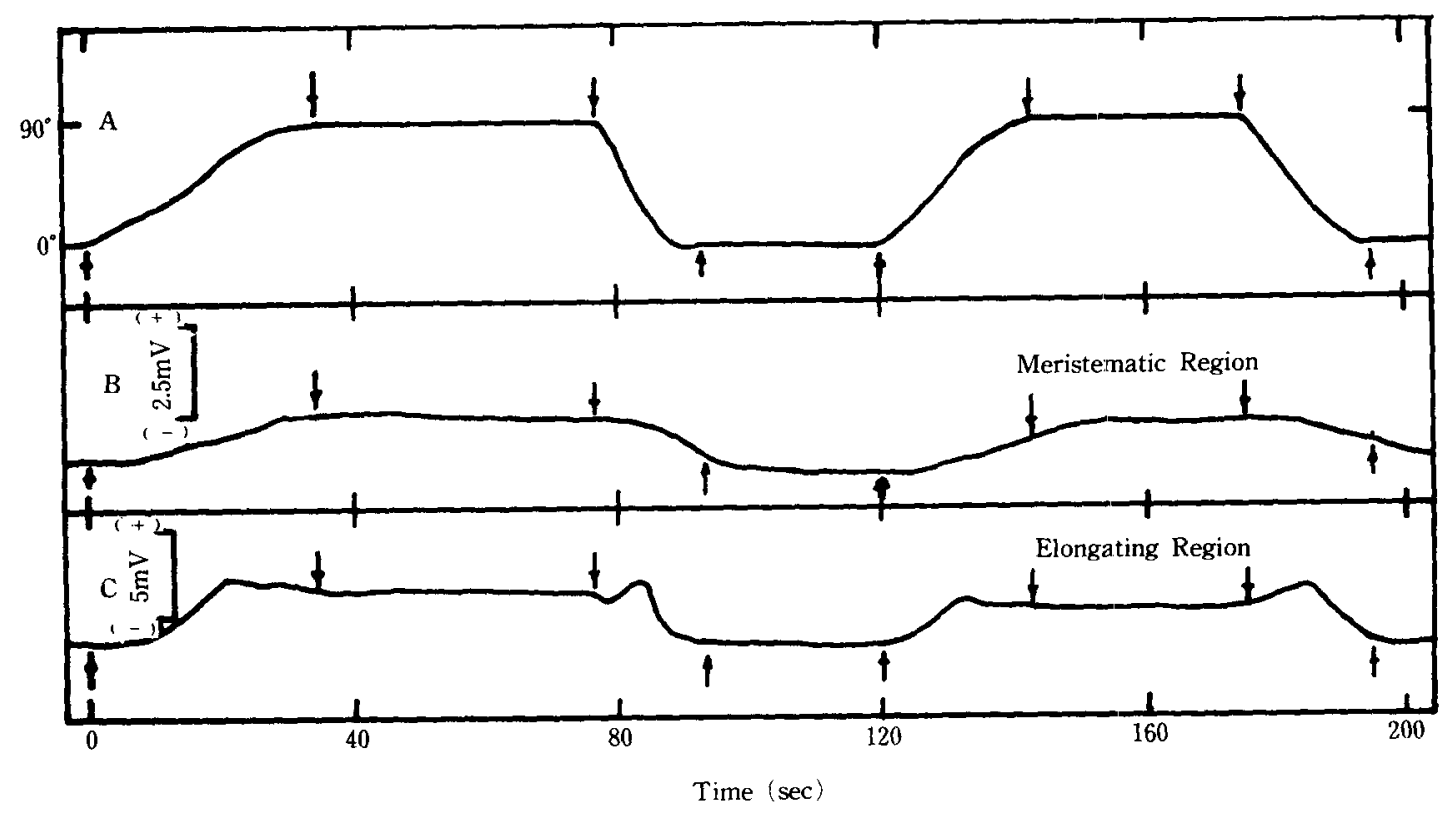

図 6 皮層細胞における膜電位の経時変化

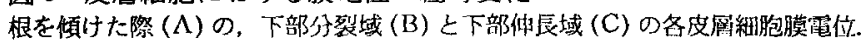


長域での成長の非一様性の結果としての重力屈性が観測 されるという連銷から成るというモデルが考えられてい る.

重力の感受部位である根冠上応答部位である伸長域の 距離は数 $\mathrm{mm}$ 以下しかなく，このことが両部域間の化 学的組成の差異を明らかにすることを困難にしてきた。 しかし直接化学組成を調べられなくても，ミクロン・ オーダーで測定細胞の位置を特定できる膜電位計測を用 いて，根を傾けることによる根冠と伸長域の膜電位の変 化からこのモデルの検証が可能である.なぜなら $2.3 に$ 示した様に重力刺激は根冠亡伸長細胞の両方の膜電位を 変化させるから，この兩部位の膜電位変化か開始する時 間差が，成長調整因子の根冠から伸長域への伝達時間に 対匛すると考えられる.

図 5 は根冠細胞, 図 6 は下部伸長細胞の結果であ る. 伸長細胞の膜電位は根冠の膜電位と同時に変化し始 めている.また根冠下部は一過性の電位变化であるのに 対し, 伸長細胞の膜電位は, 根冠細胞の膜電位より早く 安定状態に達し, 定常的に電位が維持されていることが わかる.

根冠下部，伸長域下部の脱分極は，下部側になった細 胞の起電性ポンプ活性の抑制を示していると考えられ る.膜電位と同時にトレーザ法と微小ガラス $\mathrm{pH}$ 電極法 を用いて，それぞれカリウムイオンとプロトンの輸送量 を求めると, 起電性イオンポンプの活性が高いと（膜電 位が深いと), カリウムイオンの皮層細胞内への吸収上 プロトンの皮層細胞外への放出が活発であることがわ かっている5).

・高等植物の根の起電性イオンポンプは既にプロトンポ ンプであることが知られており战，ATP（アデノシン 3 リン酸) をエネルギー源として細胞膜内外に形成され た電気化学ポテンシャルに逆らってプロトンを細胞内か ら細胞外へ放出している，一般にプロトンは細胞の呼吸 に伴って細胞内に産生し，また細胞の伸長はこのプロト ンポンプ密接に関係することが知られている ロトンの放出に伴ってカリウムイオンが細胞内に入っ て，内側の浸透ポテンシャルが下がり（すなわち浸透圧 が上がり), 細胞内に水が入り込む結果, 細胞の体積が 增す．つまり，下部側で膜電位が浅くなりポンプ活性が 隇少すると，下部側は上部に较べて細胞の伸長が押さえ られ，その結果，根は下向きに生長することになる。

以上の結果をまとめると，植物ホルモンが伸長域で不 均等分布する以前に膜電位変化が引き起こされ，屈曲を 生じるのは膜電位変化が定常状態に達した後であるこよ を示している. 成長調整因子としては植物ホルモンおよ びカルシウムイオンなどの物質が類推されてきた。 たし かに根の成長に，これらの物質がそれぞれ一定の役割を 担っているのは明らかであるが，膜電位変化が起きる僅
加数秒以内に，重力情報伝達物質として根冠から伸長細 胞に輸送される可能性は少ない，むしろ植物の場合も電 気現象が，動物の神経細胞における情報伝達機構と同様 な積極的な役割, すなわち重力情報の伝達機構の担って いる可能性がある．そこで次に，膜電位以外の電気現象 を取り上げ，電気現象による情報伝達の発生機作とその 伝達経路を検討したい.

\section{5 局所電流と表面電位}

振動電極法を用いると，根を浸した溶液中を流机る電 流を計測できる，Behrens ら (1982) ${ }^{9)}$ は，横向きにし た根の先端上部からの電流放出を観測している，鉛直な 根では根の先端は常に電流が流入している（図7A）の に対して, 横向きにすると, 先端上部の局部電流だけが 流出する樣に変化する (図 $7 \mathrm{~B}$ ). しかも応答時間は, 根 を傾けてから，根冠の場合 30 秒以内，分裂域の場合は 数分の遅れがある, 明らかにこの時間遅れは膜電位に比 较して大きい，ただ，根が傾き始めるのは約 10 分後で あるから屈曲より先行して起きる点は膜電位と同様であ る.

図810) は根ではなく，トウモロコシの子葉䩪である が，表面電位変化が屈曲後に起きることを示した重要な

A

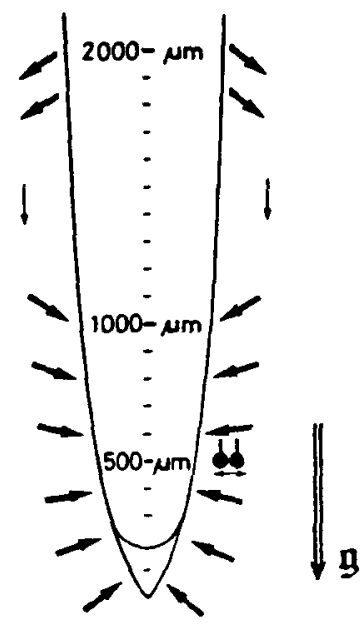

B

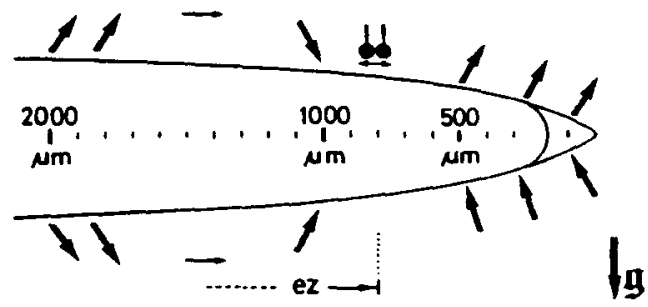

図 7 根の周辺の局所電流

A. 捨直状態と B. 水平状態, $\mathrm{ez}$ : 伸辰域 図中の山は振動電極を表わす 


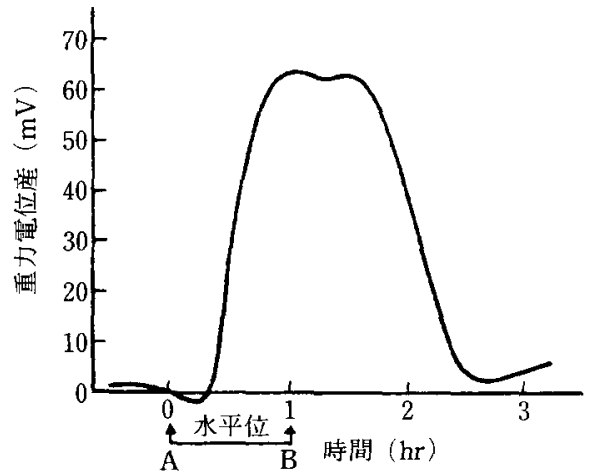

困 8 トウモロコシ子葉䩗の重力電位差 A-B 間で子葉艄を横向きにしている。

奏験である．縦軸は上表面に対する下表面の電位を示 し，傾けてから $60 \mathrm{mV}$ もプラスに変化しているが，そ れには的 15 分を要している.たしかに 15 分後の時点で は子葉鞘は既に重力と逆側に屈曲を開始し始めている. しかし根に較べて子葉鞘は厚いクチクラで覆われた，し かも空気中に突出した随分性質の異なる組織であること を考虑すべきである．根は外溶液からイオンや水を活発 に吸収しているのに対し，子葉鞘は重力屈性現象が組織 内で完結しているので，その表面電位変化はクチクラを 介して，間接的なかなりの時間遅れを伴った現象になっ ていると予想される．現に子葉鞘においても，そのクチ クラ層をはく離すると，表面電位と密接な関係のある表 面 $\mathrm{pH}$ (一般に酸成長と呼ばれ, 伸長の初期に細胞内 から細胞外にプロトンが放出され, 細胞壁の弛緩に寄与 することが知られている）は，顕著に減少する様子が観 察できるようになる。

\section{6 根内の電場形成亡屈曲}

根は重力がなけ狆ば，ら旋運動をしながら全体として は根軸を中心に対称な成長をする(このことは既に，又 ペースシャトルの宇宙実験で微小重力環境下で明らかに されている)。もし重力刺激が加われば，上記の結果か ら，根冠を含む根の先端で感受され，下側になった細胞 の起電性イオンポンプがその活性を阻害されることは明
らかである。その結果として，下側の細胞の膜電位は脱 分極していると考えられる.

根内の電場が成長を制御していることは，強制電場の 実験からも可能性が指摘できる．淡いイオン水中に根を 鉛直に固定し，数 V の直流電圧を溶液中にかけると根 は+電極に近い側の伸長が阻害されて+電極側に屈曲す る.この結果は, 電場が代替重力になり得ることを示し ている点からも興味深い

まだ研究の端鍺についたばかりで，末知の点も多い が，植物の重力屈性と電場の荓係が，予想されてきた以 上に密接であるこ上は間違いない，今後は，重力感受を しない変異種の根を用いたり，微小重力㻴境下での根の 電位を計测するつもりである。

なお筆者のデータについては，宇宙科学研究所の山下 雅道助教授, 虔応義塾大学理工学部の坂田亮教授, 太田 英二助教授に議論戴いた。芝た当研究室の沢田法子氏， 田中重氏に実験を手助けして戴いた。記して謝意を表す る。なお実験装置の一部は農林水産省農林水産特別試験 研究費補助金による.

\section{文献}

1) C. Darwin, "The Power of Movement in Plants".

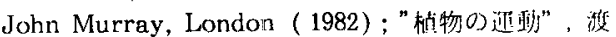
辽 仁訳，林北出版 (1988)；

2）石川秀夫，“植物の計测之㟝断”，大政健次，近藤趾!

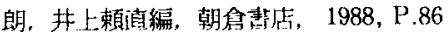

3) H.M. Behrens, M.H. Weisenseel and M.IT. Sievers, Plant Physiol., 70, 1079 (1982).

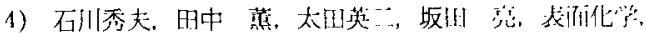
8, 37 (1987)

5) I. Ishikawa, K. Yemamura, M. l'urukoshi, E Ohta and M Sakata, Plant Cell Physiol., 25, 1015 (1984)

6) 笠毛邦弘，植物の化学調節，21，81 (1986).

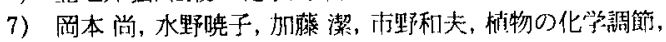
$17,95(1982)$.

8) 谷本英一，植物の化学調節，23，16(1988).

9) H.M. Behrens, D. Gradmann and $\Lambda$. Sicvers, Planta, 163, 463 (1985).

10) L. Grahm, Physiol. Plantrum, 17, 231 (1961). 